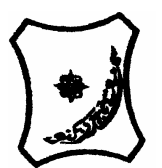

Bayero Journal of Pure and Applied Sciences, 8(2); 216 - 219

Received: September, 2015

Accepted: November, 2015

ISSN $2006-6996$

\title{
SOME BEHAVIOURAL STUDIES ON METHANOL ROOT BARK EXTRACT OF BURKEA AFRICANA (FABACEAE) IN MICE
}

\author{
Yaro, A.H., ${ }^{1} *$ Malami, S., ${ }^{1}$ Yau, J., $^{2}$ Sagoe, C.N. ${ }^{2}$ and Anuka, J.A. ${ }^{2}$ \\ 1- Department of Pharmacology, Bayero University, Kano, Nigeria \\ 2- Department of Pharmacology and Therapeutics, Ahmadu Bello University, Zaria, Nigeria \\ *Corresponding Author: malamisani@gmail.com; Tel. No.: +2348039701420
}

\begin{abstract}
Burkea africana is a plant that belongs to then family Fabaceae; it is widely spread in tropical Africa including Nigeria. It is of valuable in ethnomedicine especially in the treatment of antidote for venomous stings and bites, cutaneous and sub cutaneous parasitic infection, convulsion and pulmonary troubles. The research was conducted to evaluate some central nervous system properties of the root bark methanol extractof B. africana in mice. It involved the following animal models: diazepam-induced sleep, hole-board and walking beam assay. Results: The methanol extract showed a significant decrease in the onset of sleep at doses of $40 \mathrm{mg} / \mathrm{kg}$ and $80 \mathrm{mg} / \mathrm{kg}(p<0.05) ;$ as well as produced significant increase in the duration of sleep (40 and $80 \mathrm{mg} / \mathrm{kg}$ ) at $p<0.05, p<0.005$ respectively. The number of head dips significant/y increased at 20 and $80 \mathrm{mg} / \mathrm{kg}(p<0.05$ and 0.005 respectively). From the beam walking test for motor deficits, the result showed a significant increase in the number of foot slips at doses of $20 \mathrm{mg} / \mathrm{kg}$ ( $p<0.05) ; 40$ and $80 \mathrm{mg} / \mathrm{kg}(p<0.005)$, where as there was no significant difference in the time taken to cross the two ends of the beam (time taken to complete the task). The median lethal dose ( $\left.L D_{50}\right)$ value of $B$. africana extract was found to be 288.5 $\mathrm{mg} / \mathrm{kg}$ (i.p) in mice. The preliminary phytochemical screening revealed the presence of carbohydrates, saponins, flavonoid, aglycones, tannins, anthraquinones, cardiac glycosides, unsaturated steroids and triterpenes. Our results suggest that the B. africana extract contains biologically active compounds with potential sedative and anxiolytic properties.
\end{abstract}

Key Words: Sedation, B. Africana, Diazepam, ethnomedicine

\section{INTRODUCTION}

Drugs that act upon the central nervous system (CNS), which may either cause CNS stimulation or depression, influence the daily lives of everyone (Charles and Stitzel, 2003). Most drugs used as sleep aids are known to increase the function of the inhibitory neurotransmitter gamma amino butyric acid (GABA) in the brain (Wilson and Nutt, 2007). This enhancement of neuronal inhibition by GABA is one of the most powerful therapeutic strategies for treatment of CNS diseases such as sleep disturbances, anxiety disorders, muscle spasms, and seizure disorders (Mohler, 2001). A number of medicinal plants have been found and put into use in ethnomedicine by traditional healers in the management of many ailments for many years (Sofowora, 1993). Many medicinal plants are believed to be important source of new chemical compounds with potential therapeutic effects (Eisner, 1990). The stem bark of Burkea africana is used as antidote for venomous stings and bites, cutaneous and sub cutaneous parasitic infection, convulsion, pulmonary troubles. The plant is indigenous to Tropical Africa including Nigeria and commonly known as Bakin makarho and Apasa among the Hausas and Yoruba, respectively (Burkill, 1985). Previous works revealed that the stem bark extract of the plant possess pharmacological properties which include antioxidant and weak antimicrobial activity (Mathisen et al., 2002); antidiarrhoeal activity (Tanko et al., 2011); anticonvulsant activity (Yaro et al., 2010; Mahdi et al., 2013) and antioxidative stress of the polyphenolic-rich stem bark fractions in cell lines (Cordier et al., 2013). Therefore, this study is aimed at evaluating the root bark methanolic extract of $B$. africana for some behavioural activity in mice. To the best of our knowledge, this has not been reported elsewhere.

\section{MATERIALS AND METHODS}

\section{Animals}

Swiss albino mice of both sexes with body weight range from $18-24 \mathrm{~g}$, bred in the Animal House of the Department of Pharmacology and Therapeutics, Ahmadu Bello University Zaria, Nigeria were used. The Committee on Animal Use and Handling of the Department granted permission for their use in the experiment. They were kept in plastic cages with stainless steel wire mesh covers, floored with wood shavings to absorb urine, faecal matter and spilled water and maintained at a relative humidity and room temperature. The animals were used in compliance with the National Institute of Health Guide for the Care and use of Laboratory Animals (Publication nos. 85-23, revised 1985).

Plant Material

The plant material was collected from Sabon Gari, Zaria, Kaduna State, Nigeria, in the month of July (rainy season). 
It was identified by a taxonomist at the Herbarium Section of Department of Biological Sciences, Ahmadu Bello University Zaria. A voucher number was assigned (V/No. 075) and the specimen deposited in the Herbarium for future reference. The root bark of the plant was then allowed to dry under shade until constant weight was obtained.

\section{Preparation of the Extract}

The dried root bark was crushed and size-reduced to fine powder using mortar and pestle. Ground powder $(500 \mathrm{~g})$ was cold macerated with $1000 \mathrm{ml}$ of methanol for one week with occasional shaking. The extract was filtered and concentrated under reduced pressure, at a temperature of about $40^{\circ} \mathrm{C}$, and this gave a brown mass yield.

\section{Drugs, Chemicals and Equipments}

Diazepam (Roche Product Ltd. Switzerland) was the drug used in this study; Metler balance (P162 Gallen Kamp, UK), Weighing balance (Ohio, New York, USA), hole board $40 \times 40 \mathrm{~cm}$ with equidistant holes, wooden beam rod $(8 \mathrm{~mm} \times 60 \mathrm{~cm})$ and wooden beam rod $(8$ $\mathrm{mm} \times 60 \mathrm{~cm}$ ) were the equipments used.

\section{Diazepam-induced Sleeping Time in Mice}

Mice of either sex were divided into four groups of six each. Group 1 received normal saline $(10 \mathrm{ml} / \mathrm{kg})$ and served as control, while those in Groups 2, 3 and 4 received the extract at doses of 20,40 and $80 \mathrm{mg} / \mathrm{kg}$ (i.p.) respectively. Thirty minutes post-treatment, all the animals were administered diazepam $(30 \mathrm{mg} / \mathrm{kg}$, i.p.). Each mouse was observed for the onset and duration of sleep, with the criterion of sleep being loss of righting reflex (Wambebe, 1985; Amos et al., 2001). The time from the loss of righting reflex to recovery was recorded as sleeping time (Soulimani et al., 2001).

\section{Exploratory Behavior in Mice}

This study was done using the head-dip test on the hole-board (Ramirez et al., 1998). It was carried out using wooden board $(40 \times 40 \mathrm{~cm})$ with four equidistant holes (1 cm diameter, $2 \mathrm{~cm}$ depth). Mice of either sex were divided into five groups of six mice each. Animals in Group 1 received normal saline (10 $\mathrm{ml} / \mathrm{kg}$, i.p.) and served as control, while those in Groups 2, 3 and 4 received the extract at doses of 20, 40 and $80 \mathrm{mg} / \mathrm{kg}$ i.p. respectively. The animals in Group 5 received diazepam $(0.5 \mathrm{mg} / \mathrm{kg}$, i.p.). Thirty minutes after treatment, each mouse was placed at one corner of the board and allowed to move about and dipped its head into the holes indicating exploratory behaviour. The number of times the mice dipped their heads into the holes during the 5-minutes period was counted and recorded.

\section{Beam Walking Test for Motor Coordination} Deficits in Mice

The study was done according to the method described by Stanley et al (2005). Mice were trained to travel from a start platform along a ruler $(80 \mathrm{~cm}$ long, $3 \mathrm{~cm}$ wide) elevated $30 \mathrm{~cm}$ above the bench by metal supports, to a goal box. Trials were performed for each mouse, and were designed such that the mice tested would be aware that there was a goal box that could be reached. Mice of either sex were divided into five groups of six mice each. Group 1 received normal saline $(10 \mathrm{ml} / \mathrm{kg}$, i.p.) and served as control, while Groups 2, 3 and 4 received 20, 40 and $80 \mathrm{mg} / \mathrm{kg}$ i.p. doses of extract, respectively. Group 5 received diazepam at a dose of $0.5 \mathrm{mg} / \mathrm{kg}$. i.p. Thirty minutes later, each mouse was placed at one end of wooden beam $(8 \mathrm{~mm}$ in diameter, $60 \mathrm{~cm}$ long and elevated 30 $\mathrm{cm}$ above the bench by metal supports), and allowed to walk to the box within a maximum of $60 \mathrm{~s}$. The time taken on the beam, number of falls and the number of foot slips were counted and recorded.

\section{Statistical Analysis}

Results were presented in tables and expressed as Mean \pm SEM. The level of significance between means was tested by one-way ANOVA followed by Dunnett's Posthoc multiple test for comparison and results were regarded as statistically significant from $\mathrm{P}<0.05$.

\section{RESULTS}

The root bark extract of $B$. africana gave a brown mass yield weighing $68.47 \mathrm{~g}(13.70 \%)$. The extract produced significant $(p<0.05)$ activity at 20,40 and 80 $\mathrm{mg} / \mathrm{kg}$; a decreased onset and an increased duration of sleep. The activity was more on the duration of sleep $(p<0.005)$ at $80 \mathrm{mg} / \mathrm{kg}$ (Table 1$)$.

Also, there was significant increase in the number of head dips as a measure for exploratory behaviour; diazepam $(0.5 \mathrm{mg} / \mathrm{kg})$ was at $p<0.005$ and that of the extract $(20,40$ and $80 \mathrm{mg} / \mathrm{kg}$ ) was at $\mathrm{p}<0.05$ (Table 2).

Again, the extract gave an array of significant activity in the test for motor coordination. There was significant increase in the number of hind limb slips for diazepam $(0.5 \mathrm{mg} / \mathrm{kg})$ and the extract treated $(20,40$ and $80 \mathrm{mg} / \mathrm{kg}$ ) groups, at $\mathrm{p}<0.001$. Whereas the time taken for the mice to move along the beam was significantly $(p<0.05)$ increased at 20,40 and 80 $\mathrm{mg} / \mathrm{kg}$ (Table 3).

The preliminary phytochemical screening revealed the presence of carbohydrates, saponins, flavonoid aglycones, tannins, anthraquinones, cardiac glycosides, unsaturated steroids and triterpenes (Table 4).

\begin{tabular}{ccc}
\hline Table 1: Effect of Methanol Leaf Extract of Burkea africana (BA) on Diazepam-induced Sleep in Mice \\
\hline Treatment & Mean Onset & Mean Duration \\
$(\mathrm{mg} / \mathrm{kg})$ & of sleep $(\min )$ & of Sleep $(\mathrm{min})$ \\
N/saline $(10 \mathrm{ml} / \mathrm{kg})$ & $3.50 \pm 0.8$ & $94.30 \pm 13.30$ \\
BA 20 & $4.80 \pm 2.2^{2}$ & $76.00 \pm 40.40$ \\
BA 40 & $2.00 \pm 0.3^{\mathrm{b}}$ & $219.80 \pm 67.8^{\mathrm{b}}$ \\
BA 80 & $2.00 \pm 0.3^{\mathrm{b}}$ & $377.2 \pm 34.80^{\mathrm{a}}$ \\
\hline
\end{tabular}

Values are presented as Mean \pm SEM, $\mathrm{n}=6$ per group, $\mathrm{BA}=$ Burkea africana,

Significant difference from control (Saline) group at ${ }^{a} p<0.005^{b} p<0.05$, (ANOVA test). 
Table 2: Effect of Methanol Leaf Extract of Burkea africana (BA) and Diazepam (DZ) on Exploratory Behaviour in Mice

\begin{tabular}{ll}
\hline Treatment $(\mathrm{mg} / \mathrm{kg})$ & Number of Head Dips in $5 \mathrm{~min}$ \\
\hline N/saline $(10 \mathrm{ml} / \mathrm{kg})$ & $7.2 \pm 1.1$ \\
BA 20 & $10.4 \pm 0.5^{\mathrm{b}}$ \\
BA 40 & $11.4 \pm 2.6^{\mathrm{b}}$ \\
BA 80 & $11.6 \pm 2.2^{\mathrm{b}}$ \\
DZ 0.5 & $20.0 \pm 2.3^{\mathrm{a}}$ \\
\hline
\end{tabular}

Values are presented as Mean \pm SEM, $\mathrm{n}=6$ per group, BA = Burkea africana, DZ = diazepam, significantly different from control (Saline) group at ${ }^{\mathrm{a}} \mathrm{p}<0.005$ and ${ }^{\mathrm{b}} \mathrm{p}<0.05$ (ANOVA test).

Table 3: Effect of Methanolic Leaf Extract of Burkea africana (FV) and Diazepam (DZ) on Motor Coordination Deficit in Mice

\begin{tabular}{|c|c|c|c|}
\hline $\begin{array}{l}\text { Treatment } \\
(\mathrm{mg} / \mathrm{kg})\end{array}$ & $\begin{array}{l}\text { Number of Hind Limb } \\
\text { Slips }\end{array}$ & $\begin{array}{l}\text { Time taken for the } \\
\text { Task (s) }\end{array}$ & Number of Falls \\
\hline $\mathrm{N} /$ saline & 0.00 & $6.0 \pm 0.4$ & $0 / 6$ \\
\hline BA 20 & $3.7 \pm 0.8^{a}$ & $9.8 \pm 1.0^{b}$ & $0 / 6$ \\
\hline BA 40 & $2.8 \pm 0.7^{a}$ & $9.4 \pm 1.2^{b}$ & $0 / 6$ \\
\hline BA 80 & $3.5 \pm 0.9^{a}$ & $10.5 \pm 1.6^{b}$ & $0 / 6$ \\
\hline DZ 0.5 & $5.3 \pm 0.8^{a}$ & $8.3 \pm 0.7^{b}$ & $0 / 6$ \\
\hline
\end{tabular}

Values are presented as Mean \pm SEM, $\mathrm{n}=6$ per group, $\mathrm{BA}=$ Burkea africana, $\mathrm{DZ}=$ Diazepam, Significant difference between control (saline) group at ${ }^{\mathrm{a}} \mathrm{p}<0.001,{ }^{\mathrm{b}} \mathrm{p}<0.05$, (ANOVA test).

Table 4: Preliminary Phytochemical Screening of the Methanol Root Bark Extract Burkea africana Constituents Inference

$\begin{array}{lc}\text { Carbohydrates } & + \\ \text { Flavonoids } & + \\ \text { Tannins } & + \\ \text { Alkaloids } & - \\ \text { Cardiac glycosides } & + \\ \text { Saponins } & + \\ \text { Triterpenes } & + \\ \text { Antraquinones } & + \\ \text { Unsaturated steroids } & +\end{array}$

Key: + (present); - (absent)

\section{DISCUSSION}

The extract of $B$. Africana significantly decreased the onset of sleep, and increased the duration of sleep (Table 1). This effect may be due to inhibition of diazepam metabolism (Kaul and Kulkarni, 1978) or an action on the central mechanisms involved in the regulation of sleep (N'Gouemo et al., 1994; Amos et al., 2001). It has also been reported that activation of $\mathrm{GABA}_{\mathrm{A}}$ receptor in the CNS is known to favour sleep (Gottesmann, 2002). Hypnotic effects are classically considered to involve more pronounced depression of the central nervous system than sedation, and this can typically be achieved by increasing the dose of sedative-hypnotic drugs and therefore bring about shortening of sleep latency, increase of total sleep time and sleep efficiency (Tobler et al., 2001). Standard drugs such as diazepam and phenobarbitone are thought to produce their effects by enhancing GABAmediated inhibition in the brain (Rogawski and Porter, 1990). Thus, the shortening of sleep latency and an increased sleep duration observed in this study as well as its anticonvulsant activity previously reported by Yaro et al., (2010) could be linked to GABA-mediated CNS inhibition.
The hole-board test is a measure of exploratory behaviour in mice; to evaluate psychotic, sedative and anxiety condition in animals (Crawley, 1985; Danjuma et al., 2008). Agents that decrease this parameter reveal a sedative behaviour (File and Pellow, 1985). According to Takeda et al (1998), anxiolytic agents have been shown to increase the number of head dips in the hole-board test. Therefore, the increase in exploratory behaviour, characterized by an increase in the number of head dips may serve as a basis to predict possible anxiolytic effect of the extract in comparism to low dose of diazepam (Table 2).

Beam walking test assess benzodiazepine-induced ataxia as a predictor of sedative effects by measuring the extent of motor deficits caused by damage to the motor cortex, and it is highly defined by the extent of foot slips (Stanley et al., 2005). The extract significantly increased the number of foot slips and time taken to complete the task on the beam (Table 3). This may also be an indicator that the extract might have its effect via peripheral neuromuscular blockade (Perez et al., 1998) and mimicked the effect of benzodiazepine in producing ataxia, thus, possess sedative property. 


\section{CONCLUSION}

It can be said that the extract contains biologically active compounds which were responsible for the observed pharmacological effects. Thus, the results suggest possible central depressant and/or anxiolytic effects of the root bark extract of the plant.

\section{REFERENCES}

Amos, S., Adzu, B., Binda, L., Wambebe, C. and Gamaniel, K. (2001). Neuropharmacological effect of the aqueous extract of Sphoeranthus senegalensis in mice. Journal of Ethnopharmacolgy, 78: 33-37.

Burkill, H.M. (1985). The Useful Plants of West Tropical Africa. Royal Gardens, Kew, pp. 70-72.

Charles, R.C. and Stitzel, R.E. (2003). Modern Pharmacology with Clinical Applications ( $5^{\text {th }}$ edition), pp. 380-390.

Cordier, W., Gulumian, M., Cromarty, A.D. and Steenkamp, V. (2013). Attenuation of oxidative stress in U937 cells by polyphenolic-rich bark fractions of Burkea africana and Syzygium cordatum. Journal of Complementary and Alternative Medicine, 13: 116-127.

Crawley, J.N. (1985). Exploratory behavior models of anxiety in mice. Neuroscience and Behavioral review, 9: 37-44.

Danjuma, N.M., Aguye, I.A., Anuka, J.A., Hussaini, I.M., Zezi, A.U., Maiha, B.B. and Malami, S. (2008). Behavioural Effects of Hydroalcoholic Stem Bark Extract of Randia nilotica stapf. in Mice. International Journal of Pharmacology, 4(4): 264269.

Dubois, M.A., Ilyas, M. and Wagner, H. (1986). Cussonosides $A$ and $B$, two triterpenes saponins from Cussonia barteri. Planta Medica, 56: 80-83.

Eisner, T. (1990). Chemical prospecting. A Call for action In: Borman F.H. and Kellert, S.R. (Eds). Ecology, Economic and Ethics: The broken circles. Yale University Press, inc.

File, S. and Pellow, S. (1985). The effect of triazolobenzodiazepines in two animal tests of anxiety and on the hole-board. British Journal of Pharmacology, 86: 729-735.

Gottesmann, C. (2002). GABA mechanisms and sleep. Neuroscience, 111: 231-239.

Kaul, P.N. and Kulkarni, S.K. (1978): New drug metabolism inhibitor of marine origin. Journal of Pharmaceutical Sciences, 67: 1293-1296.

Lorke, D.A. (1983). A new approach to practical acute toxicity testing. Archives of Toxicology, 54 (4): 275287.

Mahdi, M.A., Mus'ab, A.B., Maje, I.M., Yerima, M., Malami, S. and Tanko, y. (2013). Anticonvulsant Activity of Methanolic Stem Bark Extract of Burkea africana in Mice and Chicks. Journal of Pharmacology and Tropical Therapeutics, 1(2): 21-24.

Mathisen, E., Diallo, D., Andersen, Q.M., and Malterud, K.E. (2002). Antioxidants from the Bark of Burkea Africana, an African medicinal plant. Phytotherapy Research, 16: 148-153.

Mohler, H. (2001). Pharmacology of GABA and Glycine Neurotransmission. In: Springer, H. (ed), Handbook of Experimental Pharmacology 150, pp. 101-116.

N'Gouemo, P., Nguemby-bina, C. And Baldy-moulinier, M. (1994): Some neuropharmacological effects of an ethanolic extract of Maprounea Africana in rodents. Journal of Ethnopharmacology, 43: 161-166.

\section{ACKNOWLEDGEMENT}

We appreciate the contribution of Department of Pharmacology and Therapeutics, Ahmadu Bello University, Zaria, Nigeria for approving the use of its Animal House facility and Laboratory equipments.

Perez, G.R.M., Perez, I.J.A., Garcia, D. and Sossa, M.H. (1998): Neuropharmacological activity of Solanum nigrum fruit. Journal of Ethnopharmacology, 62 (1): 43-48.

Ramirez, T.E.D., Ruiz, N.N., Arellano, J.D.Q., Maldrigal, B.R., Michel, M.T.V. and Garzon, P. (1998): Anticonvulsant effect of Magolia grandiflora L. in rats. Journal of Ethnopharmacology, 61: 143-152.

Rogawski, M.A. and Porter, R.J. (1990). Antiepileptic drugs: Pharmacological mechanisms and clinical efficacy with consideration of promising developmental stage compounds. Pharmacology Review, 42: 223-286.

Sofowora, A.A., (1993). Medicinal Plants in Africa. Spectrum Book Ltd., Ibadan, Nigeria; 2, 81-85.

Soulimani, R., Younus, C., Jamouni-Idrissi, S.,Bousa, D., Khalonki, F. and Haila, A. (2001): Behavioral and pharmacological study of Papaver rhoeas $\mathrm{L}$. in mice. Journal of Ethnopharmacology, 74: 265-274.

Stanley, J.L., Lincoln, R.J., Brown, I.A., McDonald, L.M., Dawson, G.R. and Reynolds, D.S. (2005): The mouse beam walking assay offers improved sensitivity over the mouse rotarod in determining motor coordination deficits induced by benzodiazepine. Journal of Psychopharmacology, 19(3): 221-227)

Takeda, H., Tsuji, M. and Matsumiya, T. (1998). Changes in head-dipping behaviour in the hole-board test reflect the anxiogenic and/or anxiolytic state in mice. European Jonal of Pharmacology, 350: 21-29.

Tanko, Y., Iliya, B., Mohammed, A., Mahdi, M.A. and Musa, K.Y. (2011). Modulatory effect of ethanol stem bark extract of Burkurea africana on castor oilinduced diarrhoea on experimental animals. Archives of Applied Science Research, 3(5): 122130.

Tobler, I., Koff, C., Deboer, T. and Rudolph, U. (2001). Diazepam-induced changes in sleep: Role of the a1 $\mathrm{GABA}_{\mathrm{A}}$ receptor subtype. PNAS, 98(11): 6464-6469.

Wambebe, C. (1985): Influence of some agents that affect 5-HT metabolism and receptors and nitrazepaminduced sleep in mice. British Journal of Pharmacology, 84:185-191.

Wilson, S. and Nutt, D. (2007). Treatment of insomnia. Psychiatry, 6(7): 301-304.

Yaro, A.H., Anuka, J.A., Malami, S., Yau, J. and Dansadau, U.S. (2010). Anticonvulsant Properties of Methanol Root Bark Extract of Burkea africana in Laboratory Animals. Journal of Pharmacology and Tropical Therapeutics, 1(1): 26-30 